\title{
国際建設市場に於けるプロジェクトマネジメントの 体系化を目指したコスト管理技術
}

草柳俊二*

コスト管理は競争力の向上，プロジェクト遂行力の源となる様々なデー夕を定常的か つ定量的に生み出すむのであり, プロジェクトマネジメントの根幹とあいえる. 本研究 は実地での試行結果を基に日本の建設企業の持つコスト管理特性を踏まえた方法での管 理精度の向上，コスト管理と工程管理および契約管理との統合・連携管理の技術の確立 を目的としたものである.コスト管理を中心とした統合・連携管理化は，プロジェクト マネジメントの体系化の基盤となるあのであり, 日本企業にとって国際建設市場での競 争力の保持, マネジメント能力の向上に繫がる最も重要, かつ有効な方策之考えられる.

Key Words : project management, cost control, contract administration

\section{1. はじめに}

建設プロジェクトの管理運営とは「締結した契約の思 想に従い, 仕様書に記載された品質の仕事を, 定められ た時間内に，目標とするコストで完成させること」であ り，これをいかに実現してゆくかが，その目的となる.

注目すべき点は品質, 時間およびコストの三条件の成 り立ちである．三条件設定の一般的な手順は，まず設計 図書及び仕様書によって「品質」が決められ, 次いで建 設される構造物が使用に供せられる迄での時間, つまり 「工期」が定められ, そして構造物を先の条件に従い完 成するための「目標コスト」の設定ということになる.

即ち, 三条件が扱われる順序と確定条件としての成熟 度は，1）品質，2）工期，3）コストの順となり，建設プロ ジェクトに於けるコストとは, 他の項目の確定に従い実 体が定まってくるものであり, それ故, 不確定要素が極 めて多く，複雑な管理を必要とするものとなる.

その管理は, 不確定条件を確定条件に置き換えて行く 為のシステマティックな機能と共に, 先行する品質管理 や工程管理に於ける積み残しや，誤差等を吸収してゆけ る柔軟な構造も兼ね備えていなくてはならないことにな る.コスト管理技術の確立は, すなわち, プロジェクト マネジメントの骨格の形成と言ってよいと思う.

本稿で述べるコスト管理技術は, 現実のプロジェクト での積み重ねをもとに，実施効果を検証しながら作り出 されるものであり，その前提は「日本企業が国際市場に 於いて遂行する建設プロジェクトへの適用」と言うこと になる．市場開放に伴い「協調の原理」の尊重から「競 争の原理」の厳守へと根本的な体質改善が求められ, 発 注形態の改定, 予定価格制度の再考, 特に建設コストに まつわる不透明性の是正が叫ばれている現状を考えると

*正会員. 大成建設㑣国際事業本部土木部.

（干160-06 東京都新宿区西新宿 1-25-1）
今後, 日本国内に於いても, 同様な思想のコスト管理技 術が求められて来るものと思われる.

\section{2. コスト管理の概念}

\section{(1) コスト管理とコスト経理}

コストコントロール (COST CONTROL) と, コストアカ ウンティング（COST ACCOUNTING）という言葉がある。

この二つは、同一の基盤にあるが，それぞれのもつ機 能の範囲は明らかに異なる. 前者は「コスト管理」, 後 者は「コスト経理」と訳すことができる.

コストアカウンティングとはコストコントロールの原 型を成すものであるが, その内容は, 作業品質や時間の 管理, 即ち, 生産性とは直接的な関連をもたず, 主に税 務面からコストとなった出費がいくらかを正確に算出す るものであり, その基本的手法, 及び管理目的は「集計 手法によるコスト結果の分析」と言ってよい. これに比 ベ，コストコントロールとは，コストアカウンティング を分析の情報源の一つとしているが, コストと生産性と の関連を明確にイメージし，コストを時間経過の上で捉 え, その変動幅と, 収束の方向を見通し, 分析して行こ うとするものである. 即ち, $1+1$ は必ず 2 と言った算 術的概念でなく，それが現在どの様な形であり，今後ど のような方向性を持って変化して行くのかを見出す事に 目標を置くものであり，その基盤とする手法と管理目的 は，「統計手法によるコストの経過分析」と言う事にな る.コスト管理に対する考え方は, 製造産業と, 受注産 業とでは，その内容も異なってくる．集計手法による結 果分析のコスト管理方法は製造産業に於いて主流となり 得ても, 受注産業に於いては理論的に極めて難しい事に なる. 特に建設産業においては, コスト管理そのものが 商品技術であると言ってもよく, 経過分析のコスト管理 思想が不可欠なものとなってくる。この思想でのコスト 管理は勿論, 日本国内の建設産業においても行われてい るが，残念ながら、今日に至るまで産業全体の経営資本 


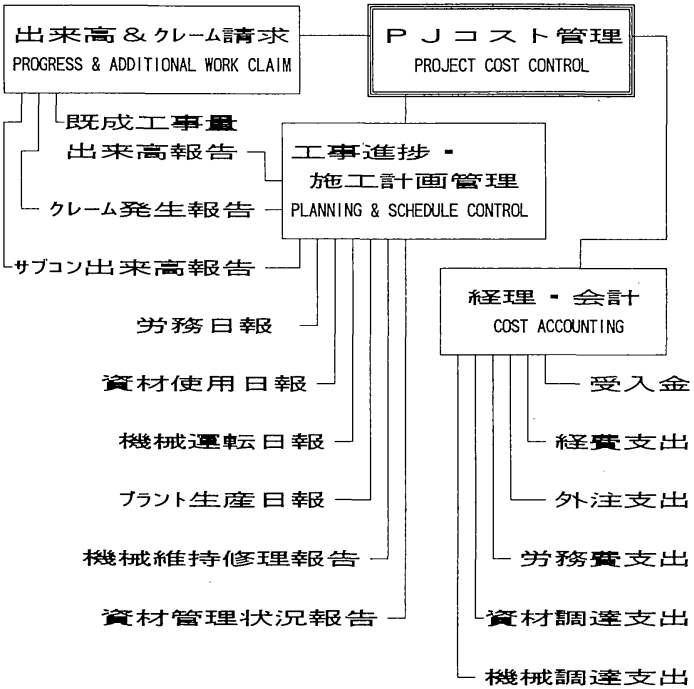

図ー1 プロジェクト・マネジメント

の体系化を目指したコスト管理

として体系化され確立された形とはなっておらず，個人 レベルでの管理手法に留まっているのが実状であると言 ってよい. コストの内容が複雑になり，契約管理に関す る意識の向上に伴い，コスト管理は，益々，透明性，客 観性が求められ，分析の手法も説得力のあるものとして 理論化して行かねばならないことになる.

\section{（2）プロジェクトマネジメントの体系化とコスト管理}

図ー 1 に示すように，コストコントロールとは原理的 にはそれ自体で稼働する機能はなく, プロジェクト遂行 に不可欠な各管理機能により定常的かつ定量的に供給さ れる精度の整ったデータを糧として，はじめて成り立つ ものである．逆にいえば、プロジェクト・マネジメント 体系化の基盤として位置づけられるものと言ってよい. 日本国内に於いても，この原理はなんら変わりはないは ずである．しかしながら，実情は各管理機能の総和とか 精度の整ったデータの定常かつ定量的な供給というよう な理論的なステップを越え, 実に“プラグマティカル” なコスト管理がおこなわれている．国内に於いて、プロ ジェクト・マネジメント自体の体系化（システム化）が なかなか研究課題として取り上げられず, 推進されない 理由はこのコスト管理の実体にあると考えられる.

国内では労務, 材料、機械、資金等の原価要素の確定 度が高く, 非常に安定し, 無駄の発生が少ない環境が確 立されており，これらを組み合わせ，作られる工事単価 そのものも, 一定の経験値をもってすれば，おのずと範 囲が定められるということになる.

これと共に，我国は相互信頼に基づく契約理念や実質 的な限定指名入札制度等, 国際建設市場からみると, 極
めて緩やかな競争原理を持つ事業環境、社会制度等に裹 打ちされているために, 言ってみれば, 始めから答の範 囲が存在しており，コストの管理はくどくどと理論的な ステップを踏まずとも，目的は達成されることになる.

以上のような理由から, 国内プロジェクトのコスト管 理は, プロジェクトマネジャー自身がコスト管理手法を 創意工夫し, 自らの手で管理, 分析を行っているのが実 態である. それ故, 客観性に欠け, 透明度が低く, 対外 的な説得力がきわめて弱いものとなっている。管理思想 も基本的にはコストアカウンティング機能を中核に置い たものであり, 残念ながら「集計手法によるコスト結果 の分析」の域を脱したものはほとんど見当たらない。

海外でのプロジェクトでは, 日本国内のような原価要 素環境とは程遠い情況にあり, ほとんどが未知数の状態 からの出発となる.これと共に, 契約条件への厳格な対 応等の理由により, 忠実に原点から積み上げてゆくコス 卜管理技術が必須条件なってくる. その手法は正に先に 述べた“コストコントロール”の内容そのものであり， 「統計手法によるコスト経過の分析」が必要となるのだ が, これを我々日本企業が行おうとする場合, 以下に述 べるような種々の準備作業が要求されることになる.

\section{3. コスト管理の原則と実施上の問題点}

\section{（1）プロジェクトコストの成りたち之管理原則}

コスト管理の有るべき姿を見出すには、先ず，管理の 目標となるコストとはどのような思想をもって構成され てゆくべきなのかを整理しておく必要がある.

通常, プロジェクトに係わるコストは, 以下のような ステップで，把握されてゆくことになる．

(1)入札時に算出した入札見積コスト

( TENDER ESTIMATED COST)

(2)契約締結時に定められた契約コスト

(CONTRACT COST : RATES)

(3)プロジェクトの開始時に設定する管理目標コスト

(TARGET COST : BUDGET)

(4)プロジェクトの遂行に伴い発生したコスト

(TO DATE COST)

(5)プロジェクト完成までに必要とされる予測コスト (TO COMPLETE COST)

プロジェクトのコスト管理を行う上での原則は、これ ら 5 段階のコストが，統一された思想の基に，同じ方向 性と精度をもって組み立てられ，互いに関連づけられて いなくてはならないということである．この原則が守ら れていないと，コスト管理は論理性に欠け，妥当性を説 明する力のないものになってしまう。

\section{（2）コスト管理の原則之問題の発生点}

日本のコントラクターの場合、前述の原則に対する認 識が極めて希薄であり, 海外プロジェクトでの失敗の大 
半はこの原則認識の欠如が原因であるといってもよい. 以下, 上記原則の欠如によって発生する問題と, その内 容に付いて述べる.

\section{a) (1)入札見積コストと(2)契約コストの関連}

入札時の見積り作業で, 契約書に記載されている支払 項目（BILL OF QUANTITIES：以下BOQ項目という) 構成の持つ意味を充分検討せず，独自の思想でコストを 算出し，これを算術的に $\mathrm{BOQ}$ Q 項目に配分するといった 方法がよくみられる. B O Q 項目がどの様に組み立てら れ，どのような契約管理思想が読めるかを検討すること はプロジェクトを入手した後に発生する条件変更による コスト変動を予測する上で, 大変重要な事となる. 又, 契約締結までの交渉に於いて, 契約額の削減が要求され た場合など， $\mathrm{B} \mathrm{O} \mathrm{Q}$ のどの項目をどの程度調整したら最 も有利かを，その場で結論付けなければならない事にな る. 上記の検討がされていないと，単純に契約単価を一 率に滅ずるとか, 削隇総額だけを合意し, 調整方法を明 確にせぬままで契約すると言ったことになる.

b）（2契約コストと(3)管理目標コストの連携

入札見積コストと同様に，管理目標コストについても B O Q 項目との連携や，それぞれの項目がもつ条件が吟 味されずに組み立てられてしまう傾向がみられる，毎月 の出来高算定及び支払のべースとなる B O Q 項目と管理 目標コストの項目が連携していないということは, 工事 の対価として受け取るコストとその遂行に要した実際の コストとの対比がシステマティックに成されず，常に二 本建てのコスト管理をおこなう形となる. 多くの時間と エネルギーを要しながら結果としては, 工程管理や契約 管理との連携に必要な論理性を備えたものにならない。

c ）(3)管理目標コストと(4)プロジェクトの 遂行に伴い発生したコストの統一管理

プロジェクトの遂行に伴い発生したコストが, 管理目 標コストの項目に従い，一定の精度をもって仕分けされ なければ，コスト管理は全く意味のないものとなってし まう。発生コストを仕分けする方策は, 日々の労務及び 建設機械の作業日報や資材倉庫の出庫伝票等の分析によ っておこなわれるもので、これらの業務処理に係わるシ ステムの確立が必要となる. 統計手法を用いたコスト管 理の実施には, 工事の遂行に係わる各種作業内容の特定 化 (作業範囲, 内容, 単位, 仕様等を定義する事) が必 要であることは改めて述べるまでもない。これと同時に 業務処理の迅速化と精度の統一した業矛処理デー夕の確 保のために「プロジェクト遂行に関わる全業務のシステ 么化」即ち, 必要業務の処理内容, 手順, 精度, 担当者 の責任と権限等を一貫した法則に基づき体系化し, 明文 化することが必要となてくる. 欧米企業のように, 明確 な自社の作業基準書( WORK STANDARD MANUAL)を持たな い日本の建設企業が, 高精度のコスト管理を目指しシス
テム化を進めようとする場合「業務のシステム化」とう 膨大な量の作業をおこなわなければならない事になる. この点が理解されずデータ処理手段のコンピューター化 だけが先行してしまい, デー夕の精度統一はもとより, 収集もままならず崩壊した例は実に多い。結局, 発生コ ストの仕分けを経理処理伝票に依存するような状態から 抜け出せず，管理精度は低下してしまうことになる。

d) (4)プロジェクトの遂行に伴い発生したコスト

と(5)完成までに必要となる予測コストの比較分析

プロジェクトの遂行に伴い発生したコストと完成迄に 必要となる予測コストが同一の基盤のもとで管理されて いないと言ったケースは論外である。 しかしながら，実 際には, プロジェクトの開始時に確固たる方針でコスト 項目が設定されず, 項目の改定が絽り返され, 発生コス トの仕分けが不明暸となり, 完成迄の予測コストの項目 と乘離してしまうケースがかなりある.

\section{（3）契約理念亡コスト管理の実体}

以上のような問題点は, 日本の建設企業が共通して持 っているものであり，このような結果となるのは，下に 述べるような日本の建設産業の持つ独特な契約理念に起 因するものと思われる。

国内に於ける建設契約の根本理念は「事業主より工事 という表現に含まれる全ての事項を遂行することを請け 負った」と言うものであるといってよい，それ故に，そ の積算及びコスト管理に関する理念は, 突き詰めて言え ば「総額でいくら」であり，その内容を何処まで表現す るか, どう扱うはコントラクター自身の意思で決めるも のであると言う考えが根底にある。これは国際建設市場 での契約理念と著しく異なったものである. 国際市場の 建設契約では, 工事全体の遂行を請け負ったのではなく

「契約に含まれる工事項目の遂行を請け負った」との理 解が基盤となる。従って, 入札時の積算手法は請負総額 を算出するためのものでなく, 契約書にある項目がそれ ぞれどの様な条件で組み立てられているかを知り, それ がいくらなのかを算出するものであり, 契約総額は, 単 にそれらの和に過ぎないと言うことになるのである.

\section{4. 国際建設市場の事業環境に適合する コスト管理システムの確立 \\ （1）コスト管理項目設定の基本方針}

a ）コスト管理項目編成とそのシステム化

コスト管理をおこなうためには, まずコスト管理項目 （COST CONTROL ITEMS）を設定しなければならない. 項 目の設定はコスト管理の精度, 方向性, 機能性等を決定 付けるものであり，コスト管理の戦略立案ともいえる極 めて重要な作業となる. コスト管理項目は総てのプロジ ェクトに共通したものであることが本部での管理, 経理 処理, あるいはコストデータの活用といった面からする 


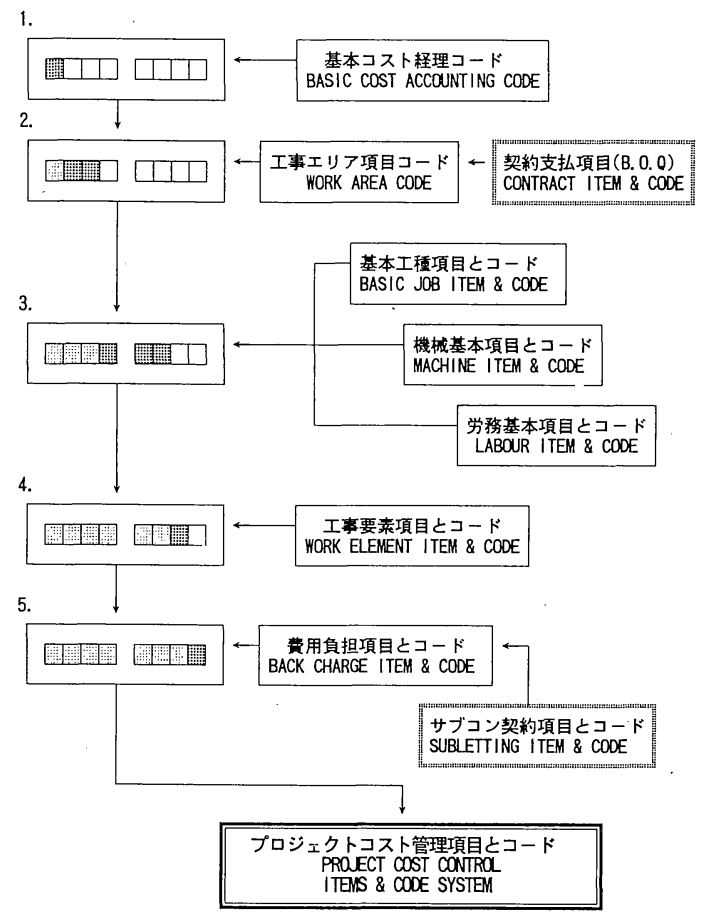

図ー2 コスト管理項目の設定とコード編成

と望ましい姿となるのだが，現実には難しい話となる． コスト管理項目は, 契約形態, 工事内容, 規模, そして B OQ項目等の条件に合致させ，構成されていなくては ほとんど意味を持たないものとなる。つまり，共通性を 強めれば強めるほど, 逆に個々のプロジェクトでのコス 卜管理内容を希薄なものにしまうことになる．コスト管 理項目の編成及びそのシステム化は，それ故に，総ての プロジェクトに共通して使用出来るものを目指すのでは なく，総てのプロジェクトに共通する部分を核として， 細目はプロジェクトごとに, 実体に合わせ調整し, 作り 上げる方法がより現実的なものとなる.

コスト管理項目やコード編成を速やかに, 且つ, 共通 した概念で行えるようにするためには，あらかじめ，経 理、資材, 機械, 労務, 経費等の基本となる要素の項目 コードを定めておき，これにBOQ項目を織り込む方法 が最も有効となる．図一 2 は, その概念を示したもので ある. 具体的手法と手順に付いては第 5 章で述べる.

b） BOQ項目に対する考え方

前第 3 章で, コスト管理の原則と問題発生に付いて述 べたが，解決策としては，先ず入札見積作業の段階にお いて, B O Q 項目を取り込だ見積り項目の設定処置を行 っておくことであり，これによりプロジェクトのコスト 管理はかなり軌道付けがなされることになる．尚，B O
Q項目をそのままコスト管理項目とする事は, 理論的に も，又，実質的にも非常に難しいこととなる.

第一の理由は, B O Q 項目の構成意図である. B O Q は通常, 発注者側が作成するもので, 文字通りコントラ クターへの「支払」を目的として構成するものである. 故に, 支払業務の明確化と簡素化を考え, 次いで条件変 更等によって発生す価格変更問題を極力回避するよう配 慮し, 設定する. 例えばコンクリートの支払項目に型枠 鉄筋, 時には掘削をも含めるといった設定が生まれる.

第二の理由は, 経理との関連である. 経理処理上の費 用項目に関わるシステムはどの企業体でも厳然として存 在しているものであり，B O Q 項目をそのまま取り入れ た場合，そのシステムをプロジェクトごとに組み替える と言ったこととなり，これは事実上不可能となる.

以上のような理由により, コスト管理の項目設定は入 札見積の段階より基本的な条件を一つ一つ吸収して行か ねばならないと言うことになる，尚，コスト管理から経 理を全く切り離す手法もあるが，結果的に管理を複雑に し精度を低下させるものとなり，得策でないと考える.

c）コスト管理項目より工程管理項目の設定

コスト管理項目のコード編成が成されると, これを用 いて工程管理項目( SCHEDULE CONTROL ITEMS : C.P.M. ACTIVITIES）を定める. 項目設定の基本方針は，コスト 管理項目のどのレベルまで（具体的にはコストコードの どの析までの項目を）工程管理項目として工程表に表す かを決めることである.レベル設定によって洗い出され た項目のうち経費等, 工程管理とは直接関連をもたぬ項 目は外し，間接工事など工程管理を行う上ではまとめて 表現すべき項目を整理する，又，更に細分し，表現して おくべき項目の調整作業をおこなう．以上の作業により 精度の整った工程管理の項目設定ができ, コスト管理と も整合性を持たせることが可能となる. 工程管理とコス 卜管理の連携, 即ち「時間とコストの関連」を明確に持 たせることは契約管理のうえで極めて重要なことであり 条件変更等によって発生する工事遅延や, 工事促進命令 に伴う追加費用の請求の基盤となる事実証明が明確にお こなえることになる。

d）設定すべきコスト管理の項目数に付いて

コスト管理項目の数は, 目標とする管理精度, 契約形 態, プロジェクトの規模, 種類等により決まってくる.

コスト管理項目の設定とは, 即ち, コストをどの程度 まで区分けし，管理するかということである．項目が細 目になればなるほど管理が複雑になり, 労力が増すよう

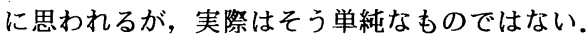

すなわち，これは物品の収納・在庫管理と同様に，収 納区分の数が少なければ少ないほど，収納時の仕事量は 少なくてすむが, 逆に, 必要物を取り出す時の仕事量は 増加する．収納区分が少ないと，それだけ同一区分内の 
表ー1 コストコード編成表

COST CODE STRUCTURING
LEVEL:

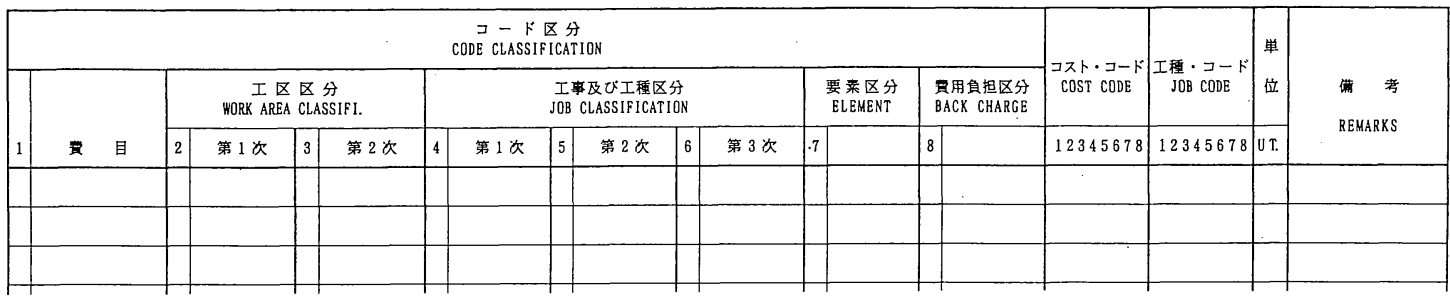

収納物の量が多くなり, 目的物を取り出す為に, より多 くの物を移動せねばならない状況が発生する事になる. 加えて, 在庫倩況や出入庫管理の効率を考えれば, 収納 区分を出来うる限り細かくしておくことが望ましいこと になる．実施例で見る限りは，パーソナルコンピュータ 一の活用により, コスト管理項目数が 2000 程度になっ ても, 管理者の仕事量は増加することなく, コスト管理 の精度が格段に向上する結果となっている. 但し, これ はコスト関連データの収集, および仕分作業の精度の向 上と効率化を図るために，先に述べたように「プロジェ クト遂行に関わる全業務のシステム化」の確立が成され たプロジェクトでの実績である.

\section{（2）コス卜管理項目のコード編成}

a）プロジェクト管理の共通言語となる

コスト管理項目のコードとは

コスト管理項目のコードはプロジェクトとこれを管理 する本部とのコスト管理上のコミュニケーションに用い られると共に, プロジェクトサイトにおいても資機材の 発注/要求, 労働力の要求, 工程管理, 出来高請求, 追 加費用請求等の各種管理機能の共通言語として使用され る大変重要な役割を持つものとなる.コード編成の基本 概念に付いては先の図ー 2 に示す通り, あらかじめ, 費 目, 材料, 機戌, 工種などの基本コードを組み立ててお き,これを一定の法則に従い組み合わせて行く方法が最 も効梁的となる. 具体的方法に付いてはコスト管理項目 の設定同様，第 5 章で述べる.

b) コストコードの桁数について

コード編成の時点では桁数が多いほど作業も楽に行え るのだが, 実際に使用する時点ではコンピューターへの 入力ミスの増加や煩雑な出力帳票のチェックと言った問 題が発生する. 故に, コードの桁数は可能な限り絞り込 むことが望ましく，様式表－1 を用い, 組み立て作業を おこなえば析数の増加にかなり歯止めをかけることがで きる. 米国でのコストコード編成の例では, 通常, 前部 4 妳, 後部 4 妳, 計 8 析の構成のものが多くみられるが これに中間部 4 桁を加え12桁程度迄が実施上からみて限 界と思われる.このようにして, プロジェクトのコスト コード編成を何例かおこなって行くうちに，共通したコ 一ド編成手法が固められてくる. しかし, 各部門が現有
するコードシステムに固執し，なかなか改定を受入れよ うとしないのが実情で，これを思い切って克服しない限 り，スリムなコードシステムを構築することは望めない 事になる.

（３）コスト管理のコンピューター処理化

コスト管理に於いて，コンピューターの活用は必須条 件となるが, それは, あくまでもデータ分析を迅速かつ 円滑に行う手段に過ぎない.コンピューターの活用は, 業務そのもののシステム化構想を固めた後に, 実施すべ きものである.それ故, システム化は業務そのものを熟 知した者が中核となって行うべきであり, コンピュータ 一の専門家だけにその構築を任せると, 実際の業務処理 と乘離が起き失敗する確率が非常に高くなる.

コスト管理のコンピューター処理化において留意すべ き点は, 始めから一括処理を目指す大型のプログラムを 作らず, 以下の様に, 業務段階に合わせ, コンパクトに プログラムを作成して行くと言うことである.

(1). 図ー 1 に示す各業務ごとに日々のデータを集計処理 するプログラムを作成する.

(2). (1)で得られた各業務処理の0UT-PUT を出来高請求工 事進捗・要素変化の把握, 経理等その管理項目に合 わせ集計処理する各プログラムを作成する.

(3). (2)で集計処理させた各データーを統合し, コスト管、 理を行う最終プログラムを作成する.

\section{5. コスト管理項目設定よコード䌅成の具体的手法}

コスト管理項目と, そのコード設定は, 入札見積の時 点より, しっかりとした方向性を持って組み立てておく ことが望ましい. この作業は, 表一 1 に示すような書式 を用い, 以下のような手順で, 一定の法則に従った形で で進める,

\section{（1）経理費目の組入れとコード付け}

日本の建設事業で用いられる経理費目はどの企業体で も大差のない構成になっており，これを第 1 位の桁およ び第 2 位の桁の一部に組み入れるのであるが, 費目構成 は以下のような変更が必要となってくる.

a ）費目の取扱区分の変更

国際市場の建設プロジェクトの契約は，一般的に単価 契約（ UNIT RATE CONTRACT）の形態を基本としており 
入札時に契約単価内訳(UNIT PRICE BREAK DOWN )の提出 を義務付けられることが多い. 最近は，一式契約におい ても，同様な要求がなされる傾向がみられる。単価内訳 の提出目的は, 入札査定の為だけでなく, 契約条件の変 更に伴う追加費用や新単価の設定等の算出根拠として用 いることであり，直接工事費（DIRECT COST）間接工事 費（INDIRECT COST）プロジェクトサイト及び本部経費 ( SITE \& HOME OFFICE OVERHEAD) 等の大枠の区分に従 い詳細項目を設定し作成することになる.

国内では一式契約が基本形となっているが, 実体から すると “完全一式契約”（FIRM LUMP SUM CONTRACT)の色 彩が極めて濃く, コントラクター側にも契約条件の変更 が即, 単価変更や追加費用の請求につながると言った考 えが定着していない，この為，経理費目の区分が直接的 に契約条件と関連を持つことはなく，税務処理上の条件 等を基準に，管理し易い方法でその区分を決めている. この習慣に従った費目区分を，そのまま単価契約のコス ト管理に用いると, 新単価の設定や追加費用の請求をお こなう場合, 煩雑なコストの分解作業が必要となり, 結 果的には交渉のタイミングを逃してしまうことになる.

b）費目の取扱順位の調整

コスト管理のオペレーションにおけるミスの発生や煩 雑さを抑えるためには, 費目コードの析数をできる限り 少なくすることが望ましい，このために，従来 1 位の桁 で表示されていた費目を 2 位, 場合によっては 3 位の桁 へと移行が求められる事になる，例えば，本部経費など は, ほとんどの場合，パーセンテージで表示される．こ れが，1000 或いは 2000 項目にもなる直接工事費と同 位の桁に位置付けされてしまうと，コード編成上大きな 無駄が生じてしまう。これを避けるために, 従来の費目 の取扱順位の調整が必要となうてくる.

\section{（2）コスト管理上必要な新項目の設定}

a ）国内の契約では表現しない項目

国内の契約では、前述のプロジェクトサイト及び本部 経費, 物価変動予備費 ( PRICE CONTINGENCY), 工事予 備費（PHYSICAL CONTINGENCY），利息（INTEREST） 及び利益( PROFIT)等を契約の単価内訳に具体的に明記 せずこれらのコストは各工事単価の中に割り込まれるか “管理費”と言った幅広い表現の項目に含められること になる.しかしながら, 単価契約のプロジェクトでは, 追加工事の発生, 条件変更や工期延長に伴う追加費用, 新単価の設定など契約問題の解決においても当然取り上 げられるべき項目となる.この為, 契約書の単価内訳に も明記し，コスト管理上も管理項目として取り上げて， 常にモニターしておくことが必要となる.

b ）工事要素コスト項目の設定

プロジェクトの遂行に必要な建設工事機械や材料を国 内のように, 要求数量を定められた時間に日々確実に調
達できるといった国は実体として極めて少ない，又，コ ンクリートや骨材等の原材料もコントラクターが自身で 生産することも稀ではない.これら工事資機材はプロジ エクト遂行に支障をきたさぬよう, 常に一定の時間的, 量的余裕をもって調達或いは生産されていなくてはなら ないものである.そのコストは先行投資的な内容を持つ もので，処理方法によっては，コスト管理の精度を著し く低下させてしまうことになる，この為に，未成工事資 材, 準備生産工事と言った工事要素コスト項目を設け発 生したコストを遅滞なく把握し, 使用時点で随時それぞ れの工事項目に振り分けを行うようにする. 工事要素項 目のコストは振り分けが行われ, 最終值はゼロとなるべ きものだが, 実際は余剩在庫, 契約数量の減少, 設計変 更等の理由により残存が発生することになる.

工事要素コスト項目の設定は, 契約数量の隇少による 未回収費用等の算出, 設計変更による未使用資機材のコ スト等を知るために即効性を持つものとなる.

ここまでの作業で，目的とするコスト管理への必要項 目の基盤設定が完了する. 尚, 契約後の追加や条件変更 等による工事はその都度, 新に項目を追加してゆく.

\section{（3）BOQ項目の織り込み}

第 4 章. 1 ). b ）で述べたごとく，B O Q項目の構成 はコスト管理の面からすると不合理な点を多く含んでい る.この為, 織り込み作業には，その内容を検討し欠落 項目の補充，細か過ぎる項目を束ね，逆に大きくまとめ すぎている項目を管理し易いように細分するといった作 業が必要となってくる．ＢOQ項目も設定に用いる一般 的手法は, 工事エリアの区分と工事種類の区分の組み合 わせによるもので，これはコスト管理項目の設定にもそ のまま適用できる原理である．この原理に従い以下のよ うな手順で項目及びコードを定めて行けば, B O Q 項目 の基本思想との乘離の無い項目設定が可能となる.

a ）工事エリア区分による項目設定とコード付け

P. 7. 表 - 2 に示すように直接工事項目の第 2 位及び第 3 位の桁を用い, 工事エリア区分を行う. 前述のごとく B OQ項目も殆どこのステップを用いて定められている のだが，出来高査定の簡易さと言った意味から詳細な区 分けにより設定されていることが多い.コスト管理の基 盤となる各作業の実績データの収集・分析の面において おのずと細分できる限界があり，コスト管理の工事エリ ア区分は、出来うる限り絞り込み 2 桁程度とする. B O $\mathrm{Q}$ 項目との対応は表の備考欄に明確に記載しておく.

b ）工種（作業）区分による項目設定とコード付け 同様に第 4 位から第 6 位までの桁を用い工種区分によ る項目およびコードの設定をおこなう．この作業も当然 のことながら B O Q 項目を出来うる限り反映させ、実際 のコスト管理を行う上で処理し易いよう考慮し組み立て てゆく。こうして決められて工種項目 (JOB ITEMS) と 
表一2 コストコード編成表

COST CODE STRUCTURING
LEVEL:

\begin{tabular}{|c|c|c|c|c|c|c|c|c|c|c|c|c|c|c|c|c|c|c|c|}
\hline \multirow[b]{3}{*}{1} & \multicolumn{15}{|c|}{$\begin{array}{c}コ ー ト ゙ 区 \text { 分 } \\
\text { CODE CLASSIFICATION }\end{array}$} & \multirow{3}{*}{\begin{tabular}{|c|} 
コスト・コード \\
COST CODE \\
12345678 \\
\end{tabular}} & \multirow{3}{*}{$\begin{array}{c}\begin{array}{c}\text { 工種・コード } \\
\text { JOB CODE }\end{array} \\
12345678\end{array}$} & \multirow{3}{*}{\begin{tabular}{|l} 
単 \\
位 \\
U T.
\end{tabular}} & \multirow{3}{*}{$\begin{array}{l}\text { 借 考 } \\
\text { REMARKS }\end{array}$} \\
\hline & & \multicolumn{4}{|c|}{$\begin{array}{c}I 区 区 \text { 分 } \\
\text { WORK AREA CLASSIF I. }\end{array}$} & \multicolumn{6}{|c|}{$\begin{array}{l}\text { 工事及び工種区分 } \\
\text { JOB CLASSIFICATION }\end{array}$} & \multicolumn{2}{|r|}{$\begin{array}{l}\text { 要带区分 } \\
\text { ELENENT }\end{array}$} & \multicolumn{2}{|r|}{$\begin{array}{l}\text { 青用萯担区分 } \\
\text { BACK CHARGE }\end{array}$} & & & & \\
\hline & 贯 & 2 & 第 1 次 & 3 & 第 2 次 & 4 & 第 1 次 & 5 & 第 2 次 & 6 & 第 3 次 & 7 & & 8 & & & & & \\
\hline 1 & 直接工事量 & 1 & 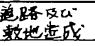 & 1 & マフセス首路 & & & & & & & & & & & 11100000 & & & $B O Q A-1.1$ \\
\hline & & & & & & 1 & $\pm I \neq$ & 1 & 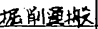 & & 一船士列 & & & & & 11111100 & 111 & $m^{3}$ & $B Q Q A-1-1-1$ \\
\hline & & & & & & & & & & & & 1 & 工㘳栈珹 & 2 & P沪建設 & 11111112 & & & (热料·油脆含坛) \\
\hline & & & & & & & & & & & & 2 & 労 & 2 & $-n-$ & 11111122 & & & \\
\hline & & & & & & & & & & & & 3 & 栈 料 & 0 & 社 & 111111130 & & & \\
\hline & & & & & & & & & & 2 & 軙岩・碩岩 & & & & & 11111200 & 112 & $m^{3}$ & $B O Q A-1-1 \cdot 2$ \\
\hline & & & & & & & & & & & & 1 & 工事栈械 & 2 & ア沪建竞 & 11111212 & & & $C-\cdots$ \\
\hline & & & & & & & & & & & & 2 & 觉弱 & 2 & $-n-$ & 11111222 & & & \\
\hline & & & & & & & & & & & & 3 & 柱 料 & 0 & 社 & 11111230 & & & \\
\hline & & & & & & & 路床，路艋 & & 路床工 & L & 碑影国 & & & & & 11121100 & 211 & $m^{3}$ & $\operatorname{Bog} A \cdot 1 \cdot 2 \cdot 1$ \\
\hline & & & & & & & & & & & & 1 & 工事找棫 & & 了三门建㪗 & 11121112 & & & $(-\cdots)$ \\
\hline
\end{tabular}

コード（JOB CODE）をそれぞれの工事エリア区分に共 通して用いることにより各工種ごとのコスト集計や，逆 に、労材機等の工事要素（WORK ELEMENT）費用の各項 目への振り分け作業が容易におこなえることになる.

\section{(4) 工事要素(NORK 日日NENT)の項目よコード設定}

各コス卜管理項目を労務、材料、及び機械等の工事要 素別の集計管理をおこなえるようにコード付けし，これ を工種コードの次に組み込む。要素分類は細分し過ぎる と発生コストの区分作業が煩雑となり全体のコスト管理 に支障を来すことになるので、できるだけ簡潔にする.

（5）費用負担(BACK CHARGE) 項目設定よコード付け 発生コストの真担処理方法を予め決めておくことは, コスト管理上で極めて重要なこととなる．そのコストが サブコントラクターの契約に含まれるもの, 企業体の相 手や自社の他部門の負担となるべきものを, 速やかに振 り分け処理ができるようにする．負担先とコードを設定 し，このコードを用いて処理する．逆に，設定コードを 用いて，各自の負担すべきコストを縦断的に洗い出し， 集計することもでき、請求処理も迅速におこなえる.

以上のような作業ステップを経て組み立てられたコス 卜管理項目と, そのコードシステムは, 遂行プロジェク トの契約思想と同じ方向性を備え，自組織のもつ共通認 識の枠にも合致し、且つ、契約管理およびコスト管理の 両面からみて合理性を備えたものとなる．これを入札見 積時から行なっておけば、前項で述べたコスト管理の原 則に関わる問題は大幅に解消されることになる.

\section{6. コンピューター処理によるコスト状兄分析}

（1）コスト管理のコンピューター処理化

コスト管理の基本形は、予算と発生コストとの比較分 析〔管理目標予算〕対〔既発生コスト十未発生コスト〕 となる．表一 3 はこの考えを基にしたプログラムベース を示したものである.このようなプログラムを用いるこ
とにより, 多種, 多様のコスト分析が迅速に出来るよう になり, 既発生コストの実態把握と未発生コストの予測 のシュミレーションが可能となってくる.

（2）コスト比較分析の手順之手法

図－3-1. -2. -3. -4 は表－3 のプログラムを基に各コ ストの比較分析を行う手順を示したものであり，4 段階 のコスト分析が実施されることになる．その内容はコス ト面で問題を含んでいる工事項目をコンピュターを用い た迅速な演算処理で摘出し，管理目標予算と実コストの 乘離を自動的に浮かび上がらせようとするもので, 内容 分析そのものは特別な技術や経験を必要とするものでは ない. 分析の目的はコストの実態を正確かつ迅速に把握 しプロジェクト全体のコストが収束すべき方向性と幅を 見いだすものである.もちろん各種アウトプットデータ により、浮き彫りにされる各工事コストの変化傾向と土 の振れ幅を見つめ, 何処を最終目標值とするかの判断は プロジェクトの責任者自身に委ねられることになる.

a) 第 1 次コスト比較分析とその手法

〔管理目標予算〕対〔現況コスト〕

第 1 次分析は各コスト管理項目ごとに, 現況コストを 把握し、それぞれを管理目標予算と対比してゆくもので ある. 図ー3.1 はその手順を示したものであり, 表一 4 は第 1 次コスト分析の帳票である.

b ) 第 2 次コスト比較分析とその手法

〔管理目標単価〕VS〔既成工事単価〕

第 2 次分析は, 各工事項目ごとに単価動向を把握する もので, 既発生コストを既成工事数量で除した数值を既 成工事単価（TO DATE UNIT RATE）とし，これを管理目標 単価 (TARGET UNIT RATE) と比較分析する.

管理目標単価と実施した工事単価との間に，どれだけ の差異が発生しているかをチェックするとともに, 実施 した工事部分のコストの実情と管理目標設定の妥当性を 把握する。既成工事単価が管理目標単価と大幅に異なっ 


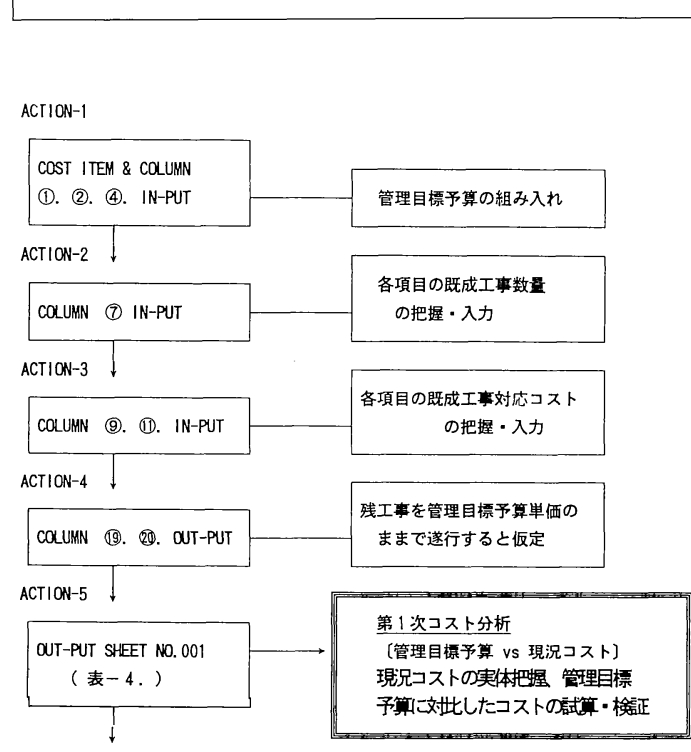

ACTION-8 $\downarrow$

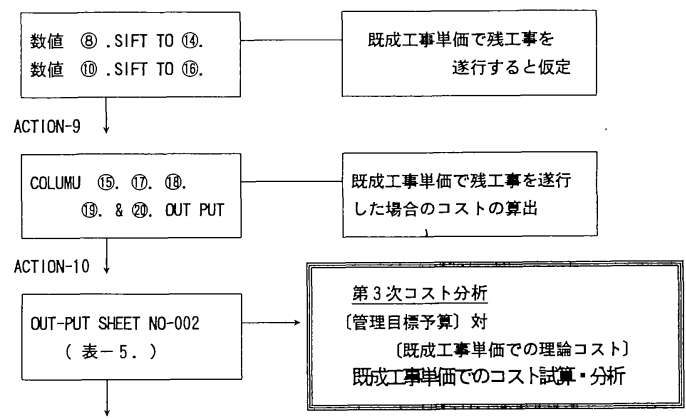

図-3・3 第 3 次コスト比較分析とその手法

〔管理目標予算〕対〔既成工事単価での理論コスト〕

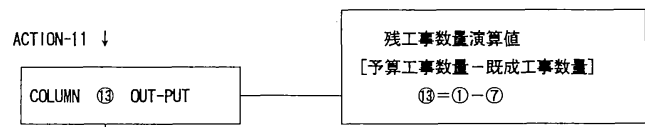

TO ACTION 6

図-3・1 第 1 次コスト比較分析とその手法 [管理目標予算]と〔現状コスト]

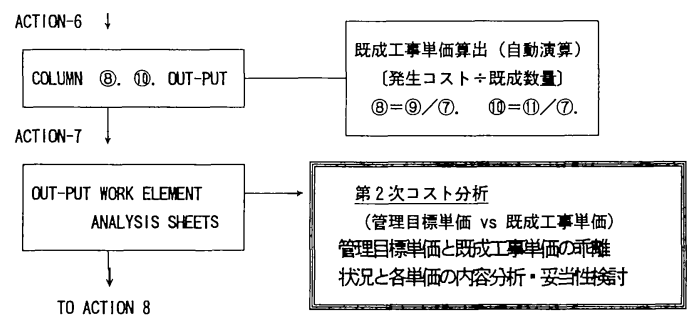

図-3・2 第 2 次コスト比較分析とその手法 [管理目標単価〕対〔既成工事単価〕

表一 3 コスト試算調書

BALANCE SHEET: TARGET BUDGET VS FORECASTED CONSTRUCTION COST

\begin{tabular}{|c|c|c|c|c|c|c|c|c|c|c|c|c|c|c|c|c|c|c|c|c|c|c|c|}
\hline \multirow{2}{*}{\multicolumn{2}{|c|}{ コスト管理項目 }} & \multirow{3}{*}{ 嵒 } & \multirow[b]{3}{*}{ 数 } & \multicolumn{3}{|c|}{ 管理目颃予算 } & 第 & 回修正 & \multicolumn{13}{|c|}{ プロジェクト・コスト虹算 } & \multirow{3}{*}{$\begin{array}{r}\text { 差積 } \\
\text { ه }\end{array}$} & \multirow{3}{*}{ 借 考 } \\
\hline & & & & \multicolumn{2}{|c|}{ ローカルポーション } & \multicolumn{2}{|c|}{ 円ポーション } & \multirow{2}{*}{$\begin{array}{l}\text { 合 故 } \\
\text { (14) }\end{array}$} & \multirow{2}{*}{ 既成 } & \multicolumn{2}{|c|}{ ローカルポーション } & \multicolumn{2}{|c|}{ 円ボーション } & \multirow{2}{*}{\begin{tabular}{|c|} 
既支出额 \\
合 \\
計 \\
四 \\
\end{tabular}} & \multirow{2}{*}{ 棫 } & \multicolumn{2}{|c|}{ ローカルボーション } & \multicolumn{2}{|c|}{ 円ボーション } & \multirow{2}{*}{\begin{tabular}{|c|} 
未支出額 \\
合 計 \\
(P)
\end{tabular}} & \multirow{2}{*}{ 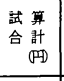 } & & \\
\hline No. & 項目 & & & 单価 & 金 額 & 单 価 & 金 積 & & & 既戒単四 & 既支出額 & 既成策偪 & 既支出積 & & & 武样西 & 未支出額 & 来戎螨 & 未支出新 & & & & \\
\hline & & & (1) & (2) & $\begin{array}{l}(3)= \\
(1) \times(2)\end{array}$ & (4) & \begin{tabular}{|l|}
$(5)=$ \\
$(1) \times(4)$
\end{tabular} & $\begin{array}{l}(6)= \\
(3)+(5)\end{array}$ & (1) & $\begin{array}{l}(8)= \\
(9) /(7)\end{array}$ & (9) . & 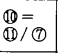 & (11) & $\begin{array}{l}(1)= \\
(9)+(11)\end{array}$ & (3) & (4) & $\begin{array}{l}13= \\
13+(4)\end{array}$ & (16) & $\begin{array}{l}10= \\
13+\infty\end{array}$ & $\begin{array}{l}8= \\
8+(1)\end{array}$ & $\begin{array}{l}19= \\
18+18\end{array}$ & $\begin{array}{l}Q= \\
6-19\end{array}$ & \\
\hline & & & & & & & & & & & & & & & & & & & & & & & \\
\hline
\end{tabular}

表一 4 コスト試算調書（既成工事対応コスト）

BALANCE SHEET: TARGET BUDGET VS FORECASTED CONSTRUCTION COST. Step 1 Analysis. 管理目榲予算) 既成工事対応コスト 残工事対応コスト

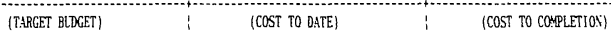
実施予定コスト 差 額

\begin{tabular}{|c|c|c|c|c|c|c|c|c|c|c|c|c|c|c|c|c|c|c|}
\hline \multirow{3}{*}{\multicolumn{3}{|c|}{ COST ITEY }} & & & & & \multicolumn{3}{|l|}{. } & & & \\
\hline & & & \multirow{3}{*}{\begin{tabular}{l}
$\vdots$ \\
$\vdots$ \\
\hdashline \\
\hdashline
\end{tabular}} & \multicolumn{3}{|c|}{ (TTRECET BLDCET) } & \multicolumn{3}{|c|}{ (COST TO DATE) } & \multicolumn{3}{|c|}{$\begin{array}{l}\text { (COST TO COAPLETTOS) } \\
\end{array}$} & \multicolumn{3}{|c|}{ (FOREESSTED COSST. COST) } & \multicolumn{3}{|c|}{ (BALALCE) } \\
\hline & & & & \multirow[b]{2}{*}{$\begin{array}{l}\text { PTTY } \\
\text { (A) }\end{array}$} & \multicolumn{2}{|c|}{ EQRTVLET (LS) } & \multirow{2}{*}{$\begin{array}{l}\text { QTTY } \\
\text { (D) }\end{array}$} & \multirow{2}{*}{ 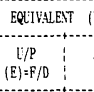 } & \multirow{2}{*}{\begin{tabular}{l|l} 
(IS) \\
\hdashline Avots \\
(P)
\end{tabular}} & \multirow[b]{2}{*}{$\begin{array}{l}\text { QTTY } \\
\text { (C) }\end{array}$} & \multicolumn{2}{|c|}{ EQLTHLETT (TS) } & \multirow[b]{2}{*}{$\begin{array}{l}\text { QTTY } \\
\text { (J) }\end{array}$} & \multicolumn{2}{|c|}{ EQQITLLEET (ES) } & \multirow[b]{2}{*}{$\begin{array}{c}\text { QTTY } \\
(y)=\mathrm{A}-\mathrm{J}\end{array}$} & \multicolumn{2}{|c|}{ EQQUVALENT (IS) } \\
\hline CODE & & DESCRIPTION & & & $\begin{array}{c}l B / P \\
(B)=C / A\end{array}$ & $\begin{array}{l}\text { (A) } \\
\text { (c) }\end{array}$ & & & & & $\begin{array}{l:l}\mathrm{l}(\mathrm{l}) \\
(\mathrm{H})=1 / 6\end{array}$ & $\begin{array}{l}\text { AWOLT } \\
\text { (II) }\end{array}$ & & $\begin{array}{c}1 V / P \\
(K)=L / J\end{array}$ & $\begin{array}{l}\text { A401x } \\
\text { (L) }=F+1\end{array}$ & & $\begin{array}{c}t / p \\
(y)=B-K\end{array}$ & $\begin{array}{l}\text { Hot } 1 \mathrm{TT} \\
(0)=C-\mathrm{L}\end{array}$ \\
\hline 13 & tier & Q HOISE & 42 & $554.00 !$ & 109.16 & $\begin{array}{r}\times 1000 ; \\
60.48\end{array}$ & $500.00 !$ & $98.46 !$ & $\begin{array}{r}\times 1000 ! \\
49.23 !\end{array}$ & 54.00 & 109.16 & $\begin{array}{r}r 1000 \\
5.89\end{array}$ & $554.00 !$ & 99.50 & $\begin{array}{l}81 \\
55\end{array}$ & 0.00 & 9.66 & $\begin{array}{r}\times 1000 \mid \\
5.35\end{array}$ \\
\hline 12450914 & KAREBOOL & & 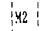 & 232.00 & $130.86 !$ & $30.36 !$ & 185.00 & 137.24 & 25.39i & $47.00 ;$ & $130.86^{\prime}$ & $6.15 i^{1}$ & $232.00 !$ & 135.95 & & 0.00 & -5.09 & $-1.188_{1}^{1}$ \\
\hline
\end{tabular}

た值を示している工事項目は、何らかの問題が発生して いる事になる、コンピュータープログラムに予め限界值 （通常土15\%程度）を設定し、これを越えた項目を自動 的に摘出し，個々に原因を見出し対策をこうじる. c）第 3 次コスト比較分析とその手法

〔管理目標予算〕対〔既成工事単価での理論コスト〕

現状のまま，つまり既成工事単価をもって残された工 事を遂行した場合どのようなコスト状況となるかを各項 


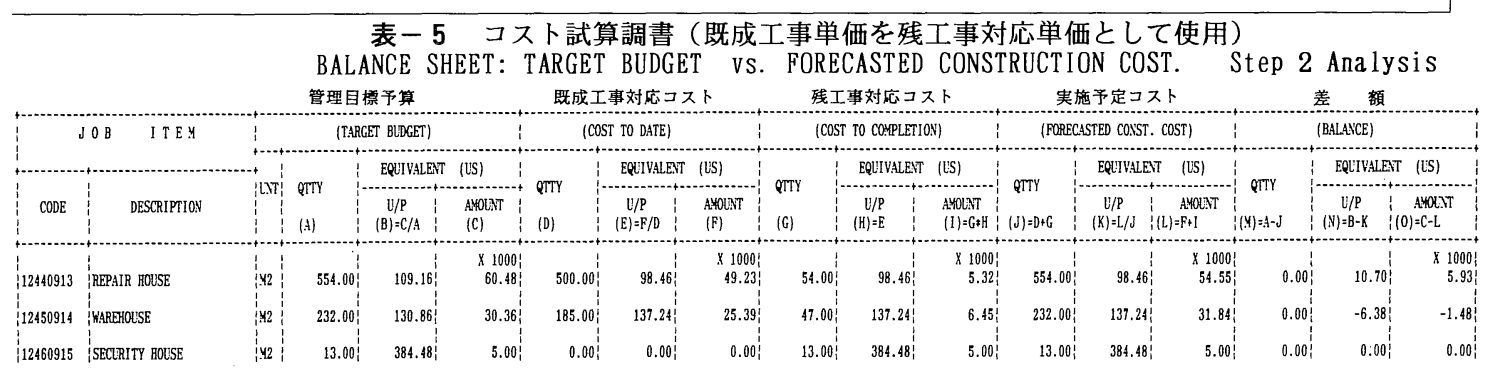

表一 6 工事单価比較分析表

UNIT PRICE ANALYSIS : TARGET BUDGET vS. TO DATE \& TO COMPLETE. as of / /

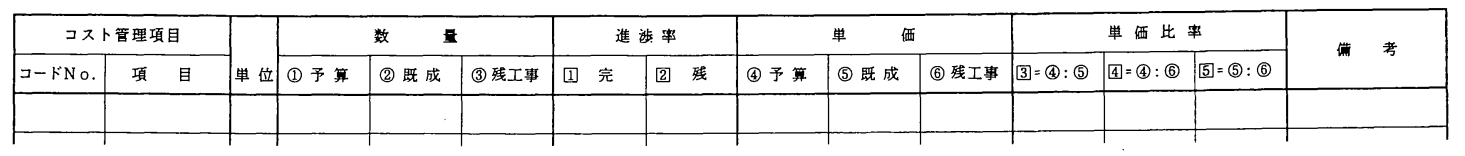

表一 7 B O Q項目コスト管理（出来高請求管理）

COST CONTROL ON BOQ TTEMS : MONTHLY PROGRESS CLAIM.

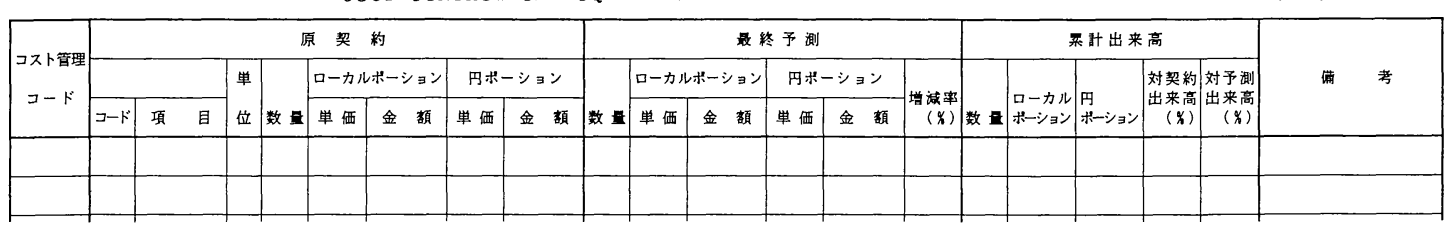

目ごとに試算し，プロジェクト全体のコスト動向を把握 する. 表一 5 は, その帳票例を示している.

d）第 4 次コスト比較分析とその手法

第 4 次コスト分析は残予算内で未完成部分の工事を消 化するためにはいくらの単価で行わねばならぬか，その 単価は管理目標単価および既成工事単価と比較して妥当 性のあるものかをチェックするものである. 本来, 残工 事単価 ( TO COMPLETE UNIT RATE) ) 種々の条件分析の 結果をもって設定されるものであるが，この段階では単 純に各工事の残予算を残工事の数量で除した数値を用い たものであり，その為あえて「演算」という言葉を付け た。表一6.は, 管理目標単価、既成工事単価及び残工 事演算単価を自動算出し, 比較できるようにしたもので ある。これら 3 単価を種々の帳票を用い工事要素のデー タレベルまで遡り比較検討分析をおこなうない, 残工事 対応の適性単価を策定する。

サブコントラクターや資機材調達先の信頼性の低さ, 現地発生コストと国内発生コスト把握の時間差, 為替レ ート変動による調整など, 国外でのプロジェクトでは, コスト現況の把握は, 多くの時間と多大なエネルギーを 必要とする. 以上のステップでのコスト分析は、コスト 面での問題項目を浮かび上がらせ, 問題の大きさを定量 的に捉えるものであり, コスト把握が迅速かつシステマ ティックに行うことができる.これにより, 問題処理対 策の思索により多くの時間とエネルギーを注ぐことがで き, プロジェクトの遂行実体と合致した“コストの経過 管理”を可能にさせることになる.

\section{7. 有効なコスト管理を行う為の施策}

\section{（1）契約出来高請求よコスト管理}

コスト管理の精度の向上には、当然のことながら契約 工事数量の増減予測, 追加工事や条件変更に伴う新単価 の設定等，しっかりした契約出来高の請求機能が組み入 れられていなくてはならない. 表一 7 はB O Q項目を主 体としたコスト管理の実施例を示したものである.

内容は, 原契約の単価と数量をべースに, 工事数量増 減, 追加工事等の変更要素を検討し, プロジェクトコス トの受入側の予測をおこなうものである. 実コストとの 連携管理は左端のコスト管理コードを用い, 工事が完了 し, 数量が確定した項目は右端の備考欄にマークされ, 未完了の工事項目と区別し検索できるようにしておく. 工事数量の増減については, 予め増減の許容幅 (単価変 更条件がある契約はその変更条件値を, その他の場合は 土15\%程度）を定め，これを越えた項目は自動的にマー クされ, モニターが可能なようにする. 単価契約のコス ト管理では, 各種条件変更が, 単価の変更に繋がるか否 かを早期検討する方策の必要があり, コスト管理上の信 頼性及び精度の向上には重要な意味を持っことになる.

\section{（2）管理目標予算の変遷之その対応}

一式契約 (LUMP SUM CONTRACT)を基調とする国内プロ ジェクトのコスト管理は「契約の総価(LUMP SUM)」を管 理対象とし行われることになる．故に，管理目標予算そ のものも, 理論的には契約総価が変わると言う前提が固 まって, はじめて変更が行われることになる. 単価契約 
表一8 第__回 修正管理目標予算

No. REVISED TARGET BUDGET

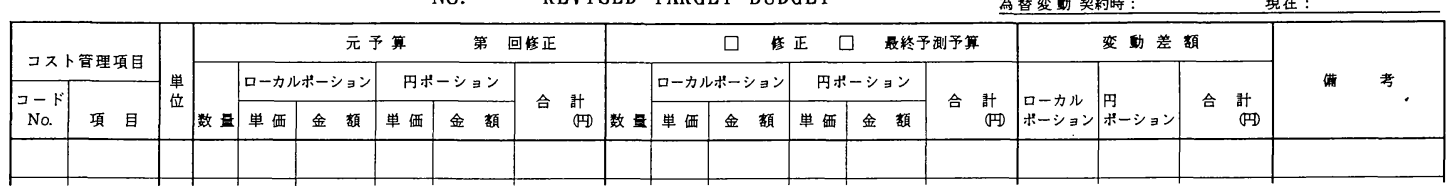

（UNIT RATE CONTRACT）の場合，コスト管理は契約総価 ではなく「契約单価（UNIT RATE）」そのものを管理対 象とする．契約総価はこの場合，BOQに記された単価 と数量によって算出された, いわゆる “暫定値”であり 各項目の数量が確定するに従い自動的に変化して行く事 になる，又，国外のプロジェクトでは急激なインフレー ションや為替変動等により管理の基準値そのものが変化 する事になる.コスト管理を行う上で大切なことは，む しろ,こうした条件変更に柔軟に対応し, 迅速な措置を とることである.この為、管理目標予算の変更内容を時 系列的に記録, 観察し予算の最終的な数値を予測する分 析手法が必要となってくる. 条件変更に対する柔軟な対 応が欠如すると、コスト管理は現実と離れた、意味の無 い数字を扱う結果となる. 表一8 は予算の变遷を把握す るプログラムベースで、元予算に, 数量の増減や, 施工 条件の変更による単価変更や追加工事, 為替変動や等に よる予算の変更要因を適宜インプットし, 現状を正しく 捉えた管理目標予算の保持を目的としたものである.

\section{8. あとかき}

国際建設市場は国内のような「信頼と協調の原理」と いったものはほとんど期待できない。このような市場に 於いては、設計や施工等の純生産技術はもちろん「信頼 と協調の原理」の市場に於いては必要とされなかった種 類と内容の管理技術, 即ち「相互不信頼の領域」を補完 する技術と，論理性と客観性を備えた管理技術が求めら れることになる.コスト管理はプロジェクト管理機能の 総和として位置付けられるものであり，その理論と技術 はプロジェクト・マネジメントの根幹であり, 大系化の 骨格を形成するものとなる.

本稿で述べたコスト管理技術は現実のプロジェクトに
於いて, その有効性が実証されているものであり, デー 夕の精度と信頼性については従来の方法に比べはるかに 高いものとなっている.これらのデータは契約管理に必 要な事実の定量的分析と害証に活用され役立っている.

工程管理との連携については項目の関連設定により, 一応コストと時間の関連付けが成されているが, 工程管 理自身の内容整備を行い、さらに連携内容の向上を進め てゆく必要があると考えている.

本稿では, 国際建設市場のプロジェクトに於いて必要 とされる新しいコスト管理技術に付いて述べたが, 透明 度の高い, 論理性を備えた, 説得力のあるコスト管理技 術の実現は, 現在の日本国内の建設事業に於いても求め られているものであると言えよう．建設産業の経営資本 の充実と言った観点をもって，コスト管理技術を見つめ 直し, 体系化を進めて行く時期にきていると考える.

謝 辞: 本論文の執筆にあったて清水建設称土木本部見 積部長 工博 隈元 力氏に御指導を賜った, また東京 大学工学部土木工学科 国島正彦教授にも貴重なご意見 をいただいた。ここにに記して謝辞といたしたい。

\section{参 考 文 献}

1) S. Kusayanagi and P. B. Hatley:Look Again at Qua 1ity Circles, ASCE ENGINEERING MAGAZINE. Apr. 1984.

2)草柳俊二・渡辺 健・隈元 力: 海外プロジェクトに における問題点と工事コスト管理に付いて, 土木学会 第47回年次学術講演会, 第 6 部 一般講演 $\mathrm{VI}-16$. 3) 草柳俊二・隈元 力・渡辺 健 : 海外プロジェクトに おける問題点と工事コスト管理に付いて, 土木学会 第48回年次学術講演会. 第 6 部 一般講演 VI-249. ( 1994. 4.12 受付 )

\section{COST CONTROL TECHNIQUE FOR SYSTEMATIZATION OF} PROJECT MANAGEMENT APPLING TO INTERNATIONAL PROJECTS Shun $j$ i KUSAYANAG I

The international construction market is based on the stern realities of free competition. Not only design and pure construction technics but construction management shall be essential for maintaining the executive and competitive powers in the market. The cost control, it shall be the main component of the management, creates various vital data for the maintaining the powers regularly \& quantitatively. This study is about the technics for mainly the Japanese contractors for the integration between cost control and the other elements, such as schedule control and contract administration. It can be said that the said technics shall be the most important and effective element for the systematization of project management. It will be the keystone of the management in the market. 